and childhood. The Lancet Neurology, 15(3), 304-316.

NICE (2012) Epilepsies: diagnosis and management

(Clinical guideline [CGI37]). Retrieved 04-09-2019, from

National Institute of Health and Care Excellence (NICE)

Takahashi K, Tanabe K, Ohnuki M et al. (2007) Induction

of pluripotent stem cells from adult human fibroblasts

by defined factors. Cell, 131(5), 86I-872.
Yang N, Chanda S, Marro S et al. (20I7) Generation of pure GABAergic neurons by transcription factor

programming. Nature methods, 14(6), 62I.

Zhang Y, Pak C, Han Y et al. (2013) Rapid single-step induction of functional neurons from human pluripotent stem cells. Neuron, 78(5), 785-798.

\title{
Dravetsyndroom: cardiale comorbiditeit en plotse dood
}

Op 28 augustus 2019 verdedigde Sharon Shmuely haar proefschrift getiteld 'The Heart of Epilepsy: Cardiac Comorbidity and Sudden Death' aan het University College London ${ }^{I}$. Ze toont aan dat cardiale comorbiditeit bij epilepsie vele oorzaken kent en dat het een belangrijke impact heeft op mortaliteit. Shmuely volgde een groot Dravet-cohort met langdurige ECG-metingen; ze vond geen ernstige ritmestoornissen maar wel een verhoogde prevalentie van ictale QTc-verlenging.

Kinderen met het Dravetsyndroom hebben een sterk verhoogd risico op SUDEP (Sudden Unexpected Death in Epilepsy). Er wordt gedacht dat ictale ritmestoornissen hierbij een rol spelen omdat (I) de erfelijke afwijking bij het Dravetsyndroom (SCNIA) ook tot expressie komt in het hart en (2) muizen met deze afwijking overlijden aan ictale ritmestoornissen. Er is echter nog geen klinisch onderzoek gedaan naar de effecten van aanvallen op het hart bij het Dravetsyndroom. Shmuely richtte haar onderzoek daarom op twee pijlers: het beter begrijpen van de cardiale comorbiditeit bij epilepsie en de rol van het hart bij SUDEP in relatie met het Dravetsyndroom.

\section{Cardiale comorbiditeit bij epilepsie}

Het proefschrift begint met een systematisch overzicht van de relatie tussen epilepsie en het hart (Shmuely \& Thijs, 20I9). Shmuely bespreekt alle mogelijke associaties aan de hand van comorbiditeit (Keezer et al., 20I6): causaal (bijvoorbeeld epileptische aanvallen die ritmestoornissen veroorzaken of vice versa), gedeelde risicofactoren (bijvoorbeeld ionkanaal-mutaties die de vatbaarheid voor epilepsie en ritmestoornissen verhogen) of associaties die het gevolg zijn van de aanvallen of de behandeling van epilepsie (bijvoorbeeld ritmestoornissen door anti-epileptica). Voor de associatie tussen de ionkanaalmutaties en
SUDEP geldt dat de beschrijvingen nog te veel berusten op anekdotische beschrijvingen.

\section{Vroegtijdig overlijden door SUDEP}

Omdat de literatuur over de mortaliteit bij het Dravetsyndroom nogal fragmentarisch is, heeft Shmuely een scoping review geschreven (Shmuely et al., 20I6a). Er werden 676 artikelen en 86 abstracts beoordeeld, waaruit in totaal 177 overlijdens geselecteerd werden. SUDEP bleek de belangrijkste doodsoorzaak (49\%) gevolgd door status epilepticus (32\%). De meeste overlijdens (73\%) traden op voor het tiende levensjaar. Dit contrasteert sterk met de SUDEPgegevens uit de algemene epilepsiepopulaties (Harden et al., 2017). De resultaten bieden houvast bij de counseling, maar laten ook zien dat er een noodzaak is voor onderzoek naar het verloop bij het Dravetsyndroom van grotere prospectieve cohorten.

\section{Valker QTc-verlenging}

In een prospectief multicenter onderzoek bekeek Shmuely de prevalentie van ictale ritmestoornissen bij het Dravetsyndroom. Met geavanceerde T-shirts met textiel-elektroden (3-kanaals ECG en accelerometrie) verrichtte zij langdurige metingen thuis (2o dagen) bij een groep van 59 patiënten van SEIN, Kempenhaeghe, Universitätsklinikum 
Bonn (Duitsland) en University College London (Verenigd Koninkrijk). In totaal werden 19.174 uren ECG en 547 aanvallen bij 45 mensen met het Dravetsyndroom gemeten (figuur I). Opvallend was dat er veel aanvallen gemist werden door de verzorgers: in totaal 144 aanvallen met een hartslag en bewegingspatroon dat overeenkwam met de patronen bij de tonisch-clonisch insulten die wél gemeld werden. Het ging vrijwel uitsluitend (94\%) om nachtelijke aanvallen. De aanvallen in de Dravetgroep werden vergeleken met 90 controles ( 169 aanvallen) met andere vormen van epilepsie. Er werden geen ernstige afwijkingen gevonden die direct actie behoefden. Wel bleek een ictale QTcverlenging ( $\geq 60$ milliseconde) vaker voor te komen bij de Dravetgroep (12\%) dan bij de controles $(4,7 \%)$. De QTcverlenging kan wijzen op een onstabiele repolarisatie en zou het risico op gevaarlijke tachyaritmieën kunnen verhogen. Een mogelijke verklaring is dat het een reactie is van het hart op ictale saturatiedalingen: deze komen vaker voor bij het Dravet-syndroom en kunnen het QTc-interval verlengen. Een alternatieve verklaring is dat de ictale QTcverlenging een gevolg is van de SCNIA-mutatie in het hart waarbij de aanval door de mutatie een repolarisatiestoornis veroorzaakt.

\section{Buikslapen een risico voor SUDEP?}

Parallel aan bovenstaand project verrichtte Shmuely een retrospectief onderzoek (Shmuely et al., 2016b). SUDEPslachtoffers worden vaak in buikligging gevonden met tekenen van een doorgemaakte tonisch-clonische aanval. Een recente meta-analyse liet zien dat dit voor maar liefst
$73 \%$ van de SUDEP-slachtoffers geldt (Liebenthal et al., 2015). De auteurs concludeerden dat buikslapen het risico op SUDEP verhoogt en opperden dat, naar analogie van wiegendood, patiënten met epilepsie niet op hun buik moeten slapen. Op patiëntenfora is hier veel aandacht voor geweest. Buikslapen werd onder andere opgenomen als risicofactor in SUDEP safety checklists. De conclusie leek een onjuiste gevolgtrekking omdat het niet bekend is in welke houding de slachtoffers lagen vóór de fatale tonisch-clonische aanval. Bovendien was er überhaupt niets bekend over de verandering van de slaaphouding tijdens normale, niet fatale tonisch-clonische aanvallen. Om dit op te helderen werd door Shmuely gericht gezocht in de EEGdatabases van SEIN en Universitätsklinikum Bonn naar video-opnames van tonisch-clonische aanvallen (I8o aanvallen bij 90 patiënten). De aanvallen bleken een belangrijk effect te hebben op de slaaphouding. De meeste personen die bij het insult in buikligging eindigden, lagen voordat de aanval begon in een andere houding. Omgekeerd gold dat de mensen die voor de aanval op hun buik lagen, door de aanval vaak in een andere houding eindigden. Het is daarom nu te speculatief om buikslapen als risicofactor voor SUDEP te benoemen. Het bewijs dat buikslapers vaker aan SUDEP overlijden ontbreekt en het blijkt dat aanvallen vaak de slaaphouding veranderen.

\section{Praktische implicaties}

Het proefschrift van Shmuely biedt een aantal klinisch zeer relevante adviezen. Shmuely heeft laten zien dat de claim dat buikslapen het SUDEP-risico verhoogt te voor-

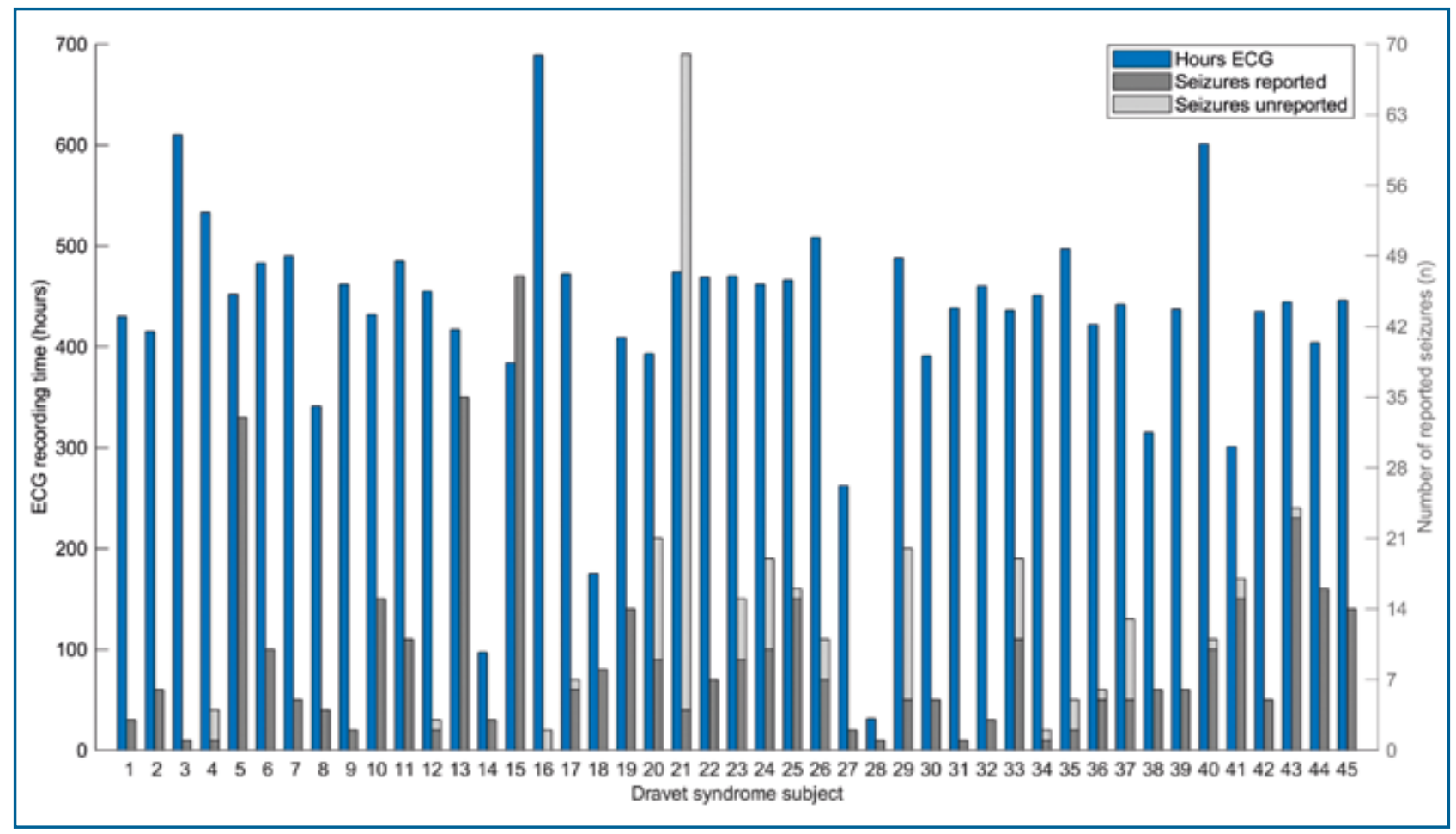

Figuur 1 Aantal uren dat het ECG werd gemeten, totaal aantal gemeten aanvallen en de proportie niet-gemelde aanvallen bij 45 mensen met het Dravetsyndroom. 
barig is. Haar prospectieve onderzoek toont aan dat routinematige screening naar ictale hartritmestoornissen bij het Dravetsyndroom niet effectief is; er werden geen klinisch relevante ritmestoornissen gevonden. Wel vond zij vaker een ictale QTc-verlenging bij de patiënten met het Dravetsyndroom dan bij de controles. Dit zou mogelijk het risico op gevaarlijke ritmestoornissen kunnen verhogen. Of dit werkelijk het geval is en of dit implicaties heeft voor het SUDEP-risico vergt langere termijn follow-up van dit cohort. Een andere belangrijke nevenbevinding was het grote aantal (waarschijnlijk tonisch-clonische) aanvallen, voornamelijk 's nachts, dat gemist werd door de verzorgers. Optimaliseren van aanvalsdetectie is daarom naast aanvalscontrole de beste interventie om het SUDEPrisico zo veel mogelijk te beperken in deze hoog-risico groep (van der Lende et al., 20I8).

\section{Referenties}

Harden C, Tomson T, Gloss D, Buchhalter J, Cross JH,

Donner E et al. (2017) Practice guideline summary:

Sudden unexpected death in epilepsy incidence rates and risk factors: Report of the Guideline Development, Dissemination, and Implementation Subcommittee of the American Academy of Neurology and the American Epilepsy Society. Neurology 2017; 88:1674-1680.

Liebenthal JA, Wu S, Rose S, Ebersole JS, Tao JX (20I5)

Association of prone position with sudden unexpected death in epilepsy. Neurology 2015; 84: 703-9.

Shmuely S, Sisodiya SM, Gunning WB, Sander JW, Thijs

RD (20r6a) Mortality in Dravet syndrome: A review.

Epilepsy Behav 2016a; 64: 69-74.

Shmuely S, Surges R, Sander JW, Thijs RD (2or6b) Prone

sleeping and SUDEP risk: the dynamics of body positions in nonfatal convulsive seizures. Epilepsy Behav 2016b; 62:176-9.

Shmuely S, Thijs RD (20I9) Epilepsy and Heart Diseases. In: Mula M. The Comorbidities of Epilepsy. London, UK: Academic Press; 2019; 159-76.

Van der Lende M, Hesdorffer DC, Sander JW, Thijs RD

(2018) Nocturnal supervision and SUDEP risk at different epilepsy care settings. Neurology 2018; 91: e1508-e18.

\section{Epilepsie met myoclonisch- atone aanvallen of het syndroom van Doose}

Kinderen met het syndroom van Doose vertonen zowel klinisch als elektrofysiologisch specifieke kenmerken. In deze bijdrage worden de typische EEG-kenmerken van het Doose-syndroom geillustreerd aan de hand van een casus.

Sinds 1989 is het syndroom van Doose opgenomen in de ILAE-classificatie van epilepsiesyndromen. Aanvankelijk droeg het de naam 'Epilepsie met myoclonisch-astatische aanvallen'; sinds de revisie van de terminologie in 2010 is het gewijzigd in 'Epilepsie met myoclonisch-atone aanvallen (EMAA)، (Berg et al., 20I0). Het beeld werd in 1970 beschreven door Hermann Doose (Doose et al., I970). Volgens de ILAE classificatie van 2017 is het een gegeneraliseerd epilepsiesyndroom met gegeneraliseerde motorische en niet-motorische aanvallen.

\section{Casus}

Het betreft een vierjarige jongen met een debuutleeftijd van de epilepsie van drie-en-een-half jaar. Er traden enkele nachtelijke bilateraal tonisch-clonische aanvallen op. Later kwamen ook absences en atone aanvallen voor. De psychomotorische ontwikkeling was normaal, totdat enkele maanden voor het epilepsiedebuut een algemene ontwikkelingsen taalachterstand werd geconstateerd. Er waren geen koortsstuipen in de voorgeschiedenis. Een oom van het jongetje heeft op kinderleeftijd epilepsie gehad (gedetailleerdere informatie ontbreekt). Andere familieleden met epilepsie zijn niet bekend. Het neurologisch onderzoek, de MRI van de hersenen en genetisch onderzoek (CGH-array) lieten geen afwijkingen zien. Het genetisch onderzoek zal worden uitgebreid met een genpanel. Gezien de typische debuutleeftijd en de verschillende aanvalstypen werd gedacht aan Epilepsie met myoclonisch-atone aanvallen (EMAA). 